Original article

\title{
COUNCIL OF WAR [SEQNENRE - KAMOSE - THUTMOSE III]
}

\author{
Negm Eddin, M. M. \\ Assoc. Prof. Department of Egyptology, Faculty of Archaeology, Cairo University, Egypt \\ mohsennegm@yahoo.com
}

\begin{abstract}
Among the many wars which depicted and documented at the ancient Egyptian history, little of them had combined "council of war", which was held by the king "Pharaoh" and his councilors to take an essential and a hard decision to begin the war, or choose military tactic. As for the dating period of the research, it contains four military councils which existed from the beginning of the 2nd intermediate period (war councils of Hyksos king Apepi "Apophis", Theban kings Seqenenre and Kamose, till the war council of the king (Thutmose III) at the 18th dynasty of the new kingdom. At last, the search makes an analysis among the four councils, about the causative of holding the council, the place of it, the identity of the councilors, the decision maker, and the result of the decision.
\end{abstract}

Keywords: Council, Old kingdom, Apophis, Kamose, Decision Maker, Thutmose

\section{Introduction}

From Old kingdom, the king had his special courtiers and advisors, so there is the common image of the king sitting in his palace, often in the "Dadw 1$\}=$ In this audience hall, the king speaks to his counselors or friends about something serious or sometimes for fun. This Event provided such an excellent description of the genre that it has now become a stock term in Egyptology which was called by Hermann [1] "Königsnovelle" Königsnovelle is a specific literary form describing a unique event in the life of the king - a single, simple, great deed. Generally written on a stela, and lies in the behavioral template which informs the pieces in question. The genre expectations inherent in the reception regime give rise to a limited set of the motifs centering upon the figure of the king [2]. The pattern is basically that the king makes a decision against the doubts and uncertainties of his councilors and demonstrates his superior judgment by the ensuing success [3]. At Westcar papyrus [4] (= Berlin Papyrus 3033), we find like an entertaining council was held by the King Khufu, it consists of a cycle of Tales within a single framing tale concerning king Khufu and the birth of the kings who are to succeed his line, the episode begins when the king one day felt with boredom, so he went around every chamber of his palace to find something for himself to entertain [5]. And the teachings for Merikare emphasis the king's need for loyal council: "Great is the great man whose great ones are great; brave is the king 
who possesses an entourage; a noble man is wealthy in great ones".[6]Although this does not state that the king created his decrees with the help of his courtiers it certainly shows the importance of courtiers to the king. Notably it acknowledges the king's need

\section{The second intermediate period}

At that period, the country was conquered by foreign people, the Hyksos (or the Asiatiques), and Egypt was divided into parts. The Hyksos predominated the Delta region until middle Egypt, The governors of Thebes controlled from Asyut till

\subsection{The Quarrel between Sqenenre}

Among the most famous literary stories of the Second Intermediate Period, "the quarrel of Seqenenrer and Apophis". a tale from Ramesside times, written some centuries after the events, and moreover it is frag-mentary. It is contained in the papyrus Sallier 1, which also includes a for others [7] .At Middle Kingdome literary Texts, some of it are that describes the King residing in his palace, waiting to be diverted by some Wise men (for example the Berlin leather Roll of Senusert 1) [8]

Elephantine, and the Nuba was ruled by the governor of Kush. The scene was set for war between Theban Kings and Hyksos, the first engagement occurred during the reign of Seqenenre Taa at the time of Ippy (Apophis) king of Hyksos.

\section{and Apophis}

copy of the Teaching of King Amenemhat 1[9], fig. (1) The composition of the story follows the pattern of the literary scheme "Königsnovelle".The opening section of the text is relatively well preserved. It describes the background for sending the message by Apophis to Seqenenre. [3]

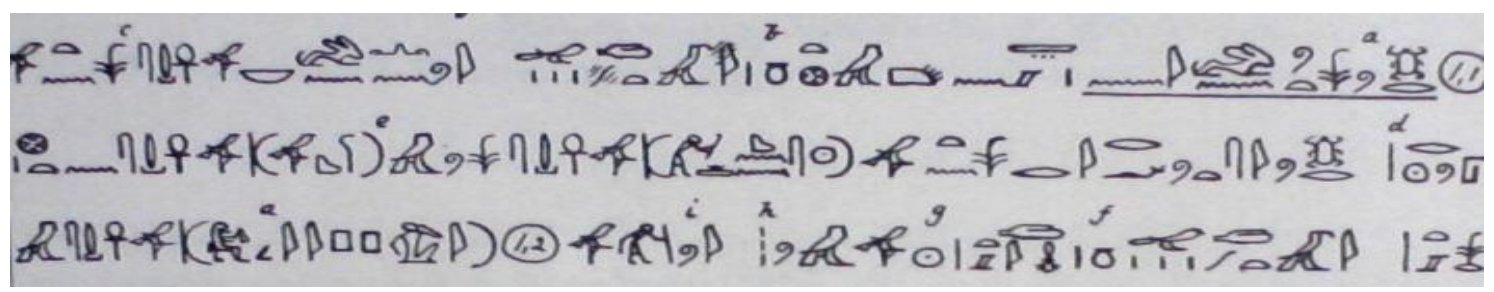

"Now it befell that the land of Egypt was in dire affliction (?) and that there was no Sovereign (as) King of the time (?). And it happened that, behold, King Seknenrer was Ruler of the Southern City. But dire affliction was in the ramu town (?), the Prince Apophis being in Avaris, and the entire land was tributary to him with their produce in full (?) as, well as with all good things of T3mri. Then King Apophis took Setekh to himself as lord, and did not serve any 2.1.1. Apophis intention and the council At this point the text is interrupted by a lacuna which extends, save for a few isolated words, to the end of the first page of the papyrus. The loss amounts to rather more than half of the passage already translated, and would have obscured the purport of the tale very seriously but for god which was in the entire land except Setekh. And he built a temple of fair and everlasting work by the side of [the palace of] Apophis, and he arose [every] day to make the daily sacrifice of [cattle] to Setekh, and the officials of [His Majesty] bore garlands of flowers (?), exactly as it is done (in) the temple of Ra'-Harakhte. Now as to King Apophis, his desire was to bring up a matter of offence (against) King Seknenrer, [the] Prince of the Southern City" [10].

\section{of Apophis}

the fact that a consultation between King Apophis and his councilors was clearly here narrated, the contents of which are repeated almost verbatim in the sequel, but it can be established, even though details in the wording have to remain unsettled. [3] 

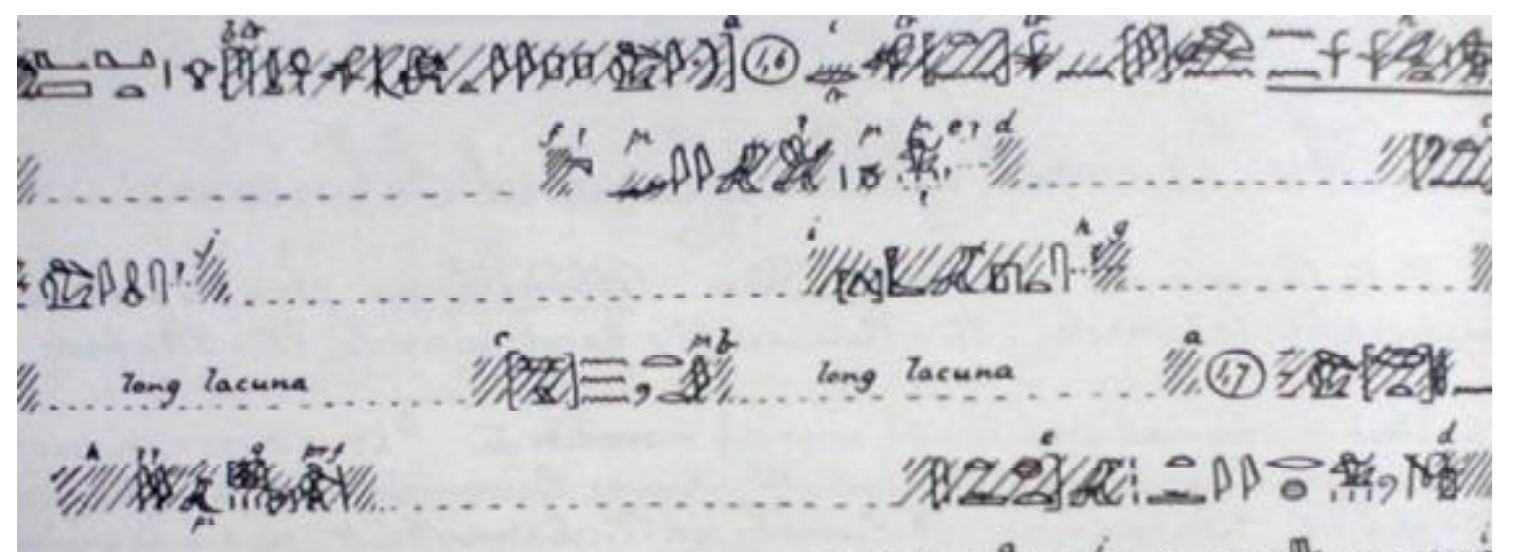

lang lacuma

ขึ(1)

U/,

"Now when many days were passed after this, King [Apophis] caused to be summoned [his] ............., $h$ [...............and said to them, "The desire of My Majesty is] to send [a messenger to the Southern City in order to bring] an accusation [against King Seknenre?." And his..... and his......... knew not how to answer him. Then he caused to be summoned his] scribes and wise men [concerning it. And they made answer to him and said, "O] Sovereign, [our Lord...... There is] a hippopotamus pool [in the Southern City. the] river Comment:

The paragraph of the text uses the introductory: hr ir m-ht hrw knw hr sa $n$ $n$ ""and then after many days after

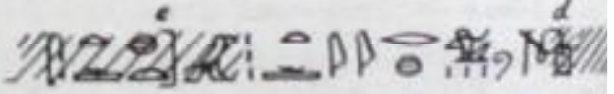

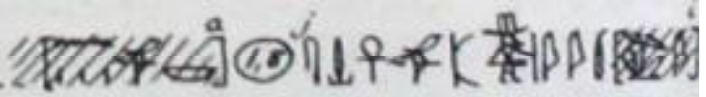
[.........] and they (the hippopotami) do not allow [sleep to come to us either by day or by] night, [but] noise [is in our ear. Let therefore] your( ?) [Majesty send] to the Prince of [the Southern City........... King Seknenrer and let the messenger say to him: 'King] Apophis [ ...] commands( ?) [Cause to be abandoned the hippopotamus pool.'.......... So shall your Majesty see who is] with him as helper, (for) he (?) does not incline to any god who is in [the entire land] except Amen-re, King of the Gods." is chief....... 10

this...."marking a different setting in time.[3]

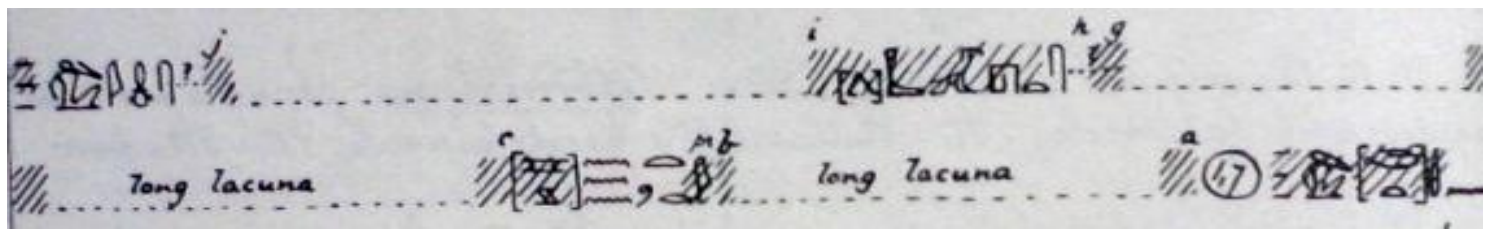

Here Apophis want to send a warning message to Seqenenre ${ }^{r}$ may be after knowing the military equipments at Thebes, so after the idea was kept in his mind, he made a council at his palace contained his wise men and excellent scribes, according to Goedicke, it is tempting to conjecture that it is part of Apophis' scheme to send a message to Seqenenrer to which there is no foreseeable reply. The stunned silence of Seqenenrea's courtiers mention later would agree with a such thesis [3]. As for the message, we can notice a among the few preserved words from this paragraph are [smi $n$ mdt] " reply to a statement ", without context, it is emphasized that the message sent was the product of Apophis's scribes, suggesting his inability to make his own decisions, an episode well paralleled in the " Königsnovelle ", but the usual form that the king makes a decision after his councilors have been unable to 
promulgated a solution was not find here. [3] After that; the tale informed us about reaching Apophis' messenger to Thebes, and he had been taken to Seqenenre's presence, then Seqenenre asked him: "Why were you sent to the southern city, that you reach me? These travels were for what?", after that the messenger delivered his message;

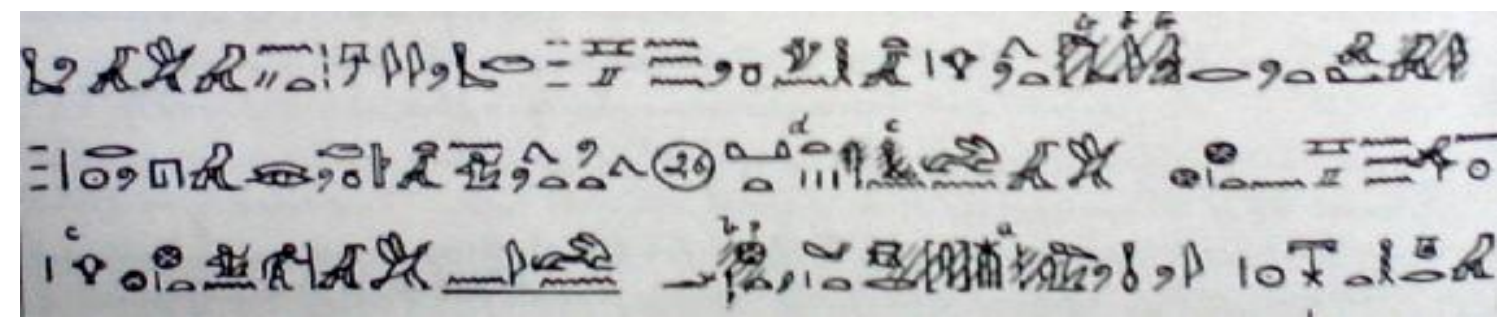

" cause to remove from the drained land the dbyw mercenaries, who are in the orient of the city, because they don't let 2.1.2. Seqenenre's reaction the sleep come to me by day or by night, as soon as, words are in his ear. " so he says.[3]

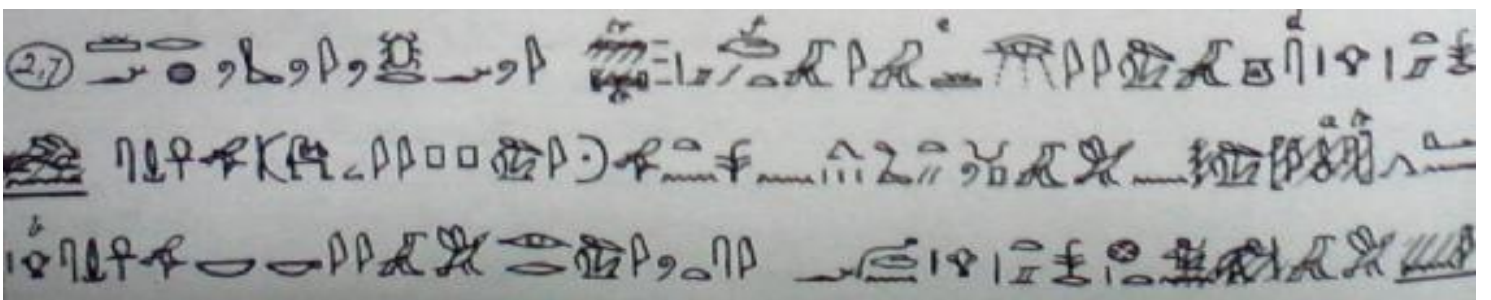

The message of Apophis stunned Seqenenre, who instantly realized its grave political meaning, and then he ordered to provide the needs for the messenger consisting of all good things, 2.1.3. Seqenenre's council after that; he told the messenger to go and tell his lord that he will do all which he had said, it seems that Seqenenre tries to appease the Hyksos king by assuring him of his loyalty. [11]

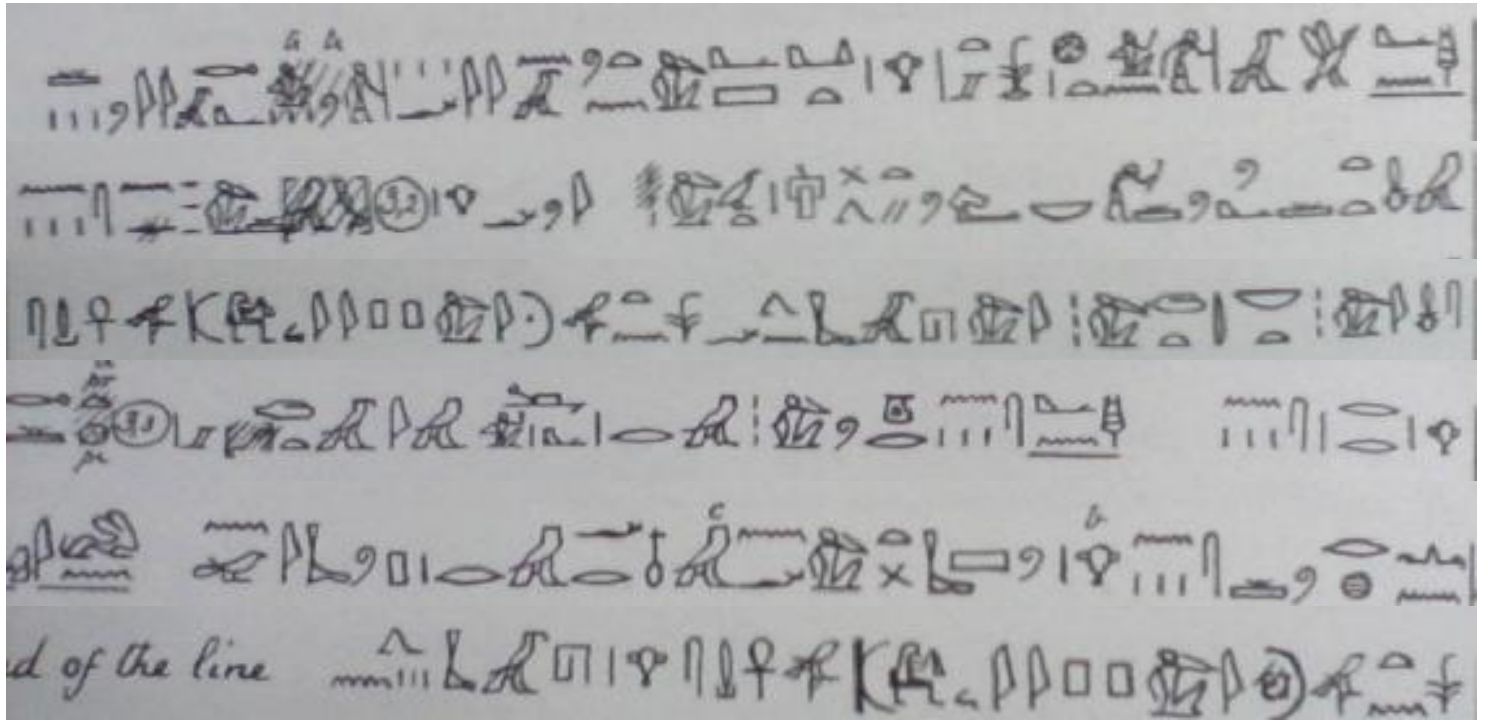

"And then the prince of the southern city caused that one summons his officials, as well as every ranking soldier of his and he repeated to them the entire issue concerning which King Apophis, 1.p.h., had sent to him. And they were silent in 
unison in great bewilderment. Not were they able to answer him 'good!' or 'bad!' Comment:

We find here at this tale, the second council which held by Seqenenre and his officials and army commander, to know their answer and decision about this hard position, but unless they support Seqenenre situation, they (as written at the papyrus) were silent in unison in great bewilderment. Not were they able to answer him 'good!' or 'bad!', but unfortunately the end of the story is not preserved, but probably related some victory of Seknenre', the hero of the tale. At last we can make comparison

\subsection{Kamose}

At the time of Kamose, the scene was set for war at the two sides, the northern (against Asiatiques) and the southern (against the Kushite), we have royal documents related to these events. Kamose had two stelae, originally set up in the temple of Amun at Karnak. One is completely preserved; of the other only the beginning has survived, fig. (2a) augmented by an ancient copy made in cursive handwriting on a scribal board
"And then King Apophis, 1.p.h., was sending to..........." 3

between Apophis' council and Seqenenre to observe the assimilations and differentiations, that the twice councils were hold at the king' palace, but there are differentiation about the members of the twice councils, as for Apophis' council contained wise men and scribes, the Seqenenre' council consisted of the officials and high military ranking, that the role of the first council to create literary message, but the role of the second to make a destiny decision.

some two centuries later [12], fig. (2b). The scribal board was first to become known as Carnarvon belong to a pair of hieratic writing-boards found among loose debris of pottery and fragmentary mummies on a ledge near the entrance to a plundered tomb in the Birabi, not far from the mouth of the Deir el Bahari valley [13]. The research is concerning with only Kamose first stele and its hieratic copy of Carnarvon as shown in the next tab.

\begin{tabular}{|c|c|c|c|c|}
\hline Topic & Council of Apophis & $\begin{array}{l}\text { Council of } \\
\text { Seqenenre }\end{array}$ & Council of Kamose & $\begin{array}{l}\text { Council of } \\
\text { Thutmose }\end{array}$ \\
\hline dialogue & Short & Short & Long & long \\
\hline Place & Palace & Palace & Palace & Army camp \\
\hline Members & $\begin{array}{l}\text { Scribes } \\
\& \text { wise men }\end{array}$ & $\begin{array}{l}\text { Officials \& ranking } \\
\text { soldiers }\end{array}$ & "ndjwt" officials & Army commander \\
\hline Decision Maker & Scribes\& wise men & $?$ & Kamose & Thutmose III \\
\hline Königsnovelle & Not typified & Not typified & typified & Nearly typified \\
\hline Reason & $\begin{array}{l}\text { Make } \\
\text { a political fraud }\end{array}$ & $\begin{array}{l}\text { Answer the } \\
\text { threatened } \\
\text { message }\end{array}$ & Kamose will & $\begin{array}{l}\text { Choose } \\
\text { march road }\end{array}$ \\
\hline Result & $\begin{array}{l}\text { Sending a threatened } \\
\text { message }\end{array}$ & $?$ & Begin liberation war & Crossing Aruna \\
\hline documented on & p. Salliet 1 & p. Salliet 1 & $\begin{array}{l}\text { Kamose } 1^{\text {st }} \text { stela \& } \\
\text { writing-board }\end{array}$ & Hall of Annals \\
\hline
\end{tabular}




\subsubsection{Kamose council}

King's order to hold a counsel:

Jeg e nd

His Majesty spoke in his palace to the council of grandees who were in his suite...10

Comment:

Kamose commanded to hold a council of war at his palace, this council "ndjwt" may be consisted of high officials, including army leaders, and naval men, were present. There is a simple sequence of policies [14]. This word "ndjwt" was not used neither at Apophis' council nor

Seqenenre' council, so the searcher suggests that the council of Kamose here was determined and consists of particular important persons, and this case was not existed at the two latter examples.

2.2.2. The dialogue:

2.2.2.1. Kamose speak: 13

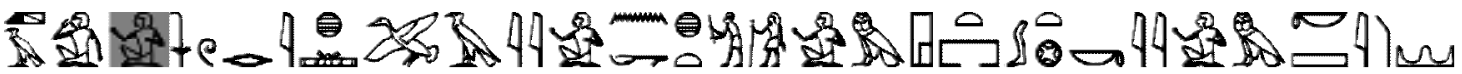

盛通

To what end am I cognizant of it, this power of mine, when a chieftain is in Avaris, and another in Kush

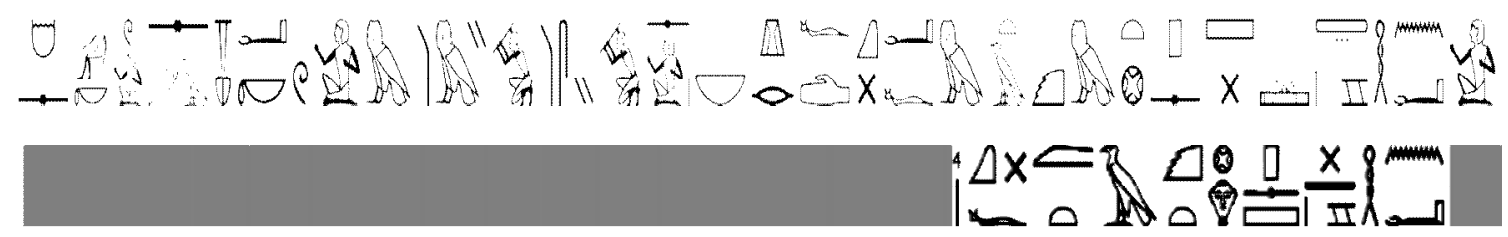

and I sit in league with an Aamu and a Negro every man holding his slice of this Egypt ? He who shares the land with me,

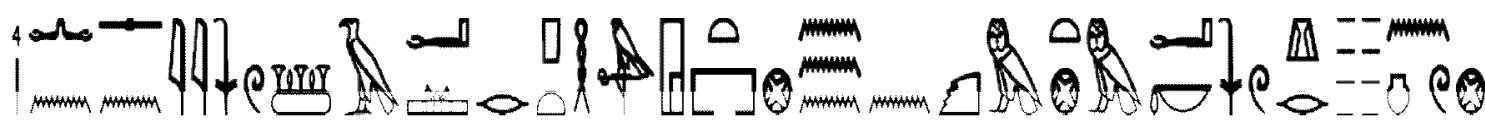

I do not pass him (??) as far as Memphis, the water(?) of Egypt. See, he holds (?) Ashmunein

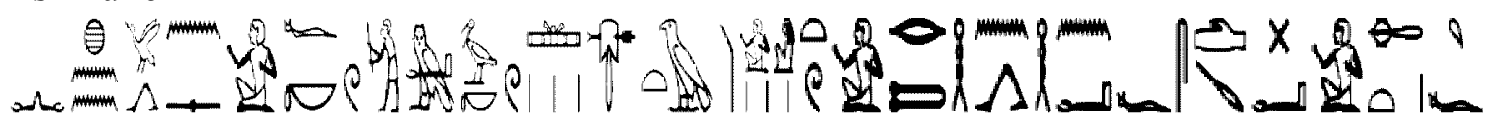

and no man rests, being wasted through servitude (?) of the Setyu. I will grapple with him and rip open his belly

Comment:

Here we have a complete dialogue between the Kamose and his councilors, that we missed this kind of speech either at Apophis or Seqenenre' council, at first Kamose began to speak to inform his councilors about the council purpose. Here Kamose reflections concern a particular political problem in Egypt and have no "nationalistic" aspirations [12]. That Asiatique sovereign controlled the north until Ashmunein, and other (the Kushite sovereign) seized Kush at Nuba, and he was sitting amongst without a real power. From this speech, we can confirm the political situation in the Nile Valley which was described, it is divided into three main spheres, one comprising "Kush", another is in Avaris, and the third is denoted as kmt "Egypt" which covered Upper Egypt. 
2.2.2.2. His Council answers:

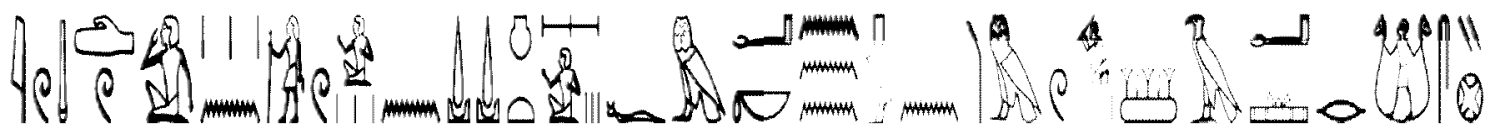

And the grandees of his Council said:-"Behold, the Asiatics have [advanced?] as far as Cusae,

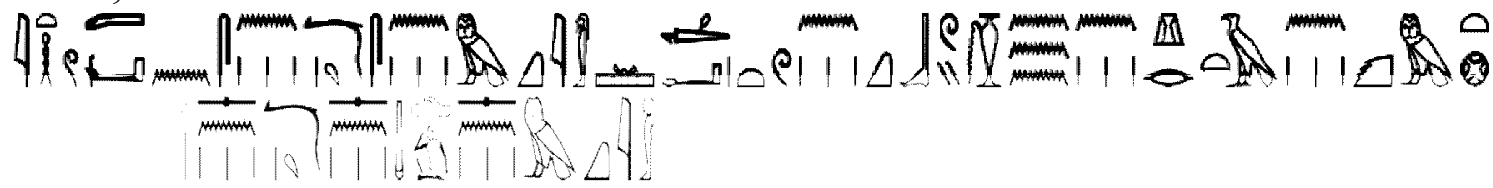

they have pulled out (?) their tongues all together. We are at ease holding our (part of) Egypt.

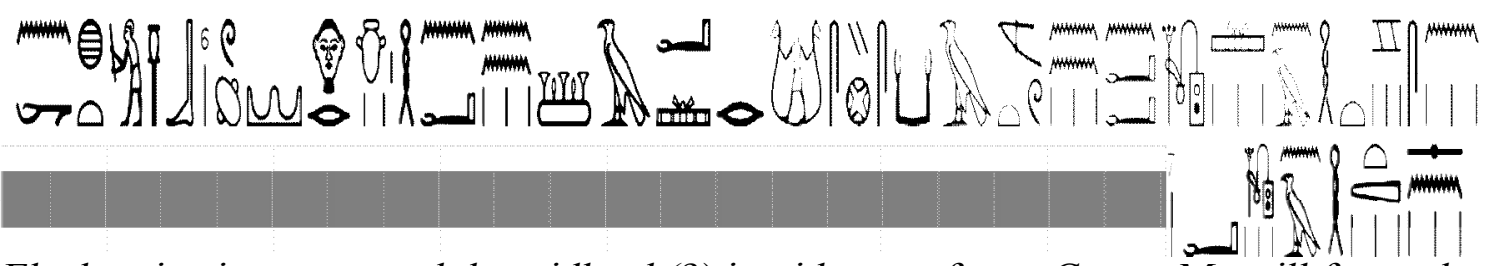

Elephantine is strong, and the midland (?) is with us as far as Cusae. Men till for us the finest of their land...

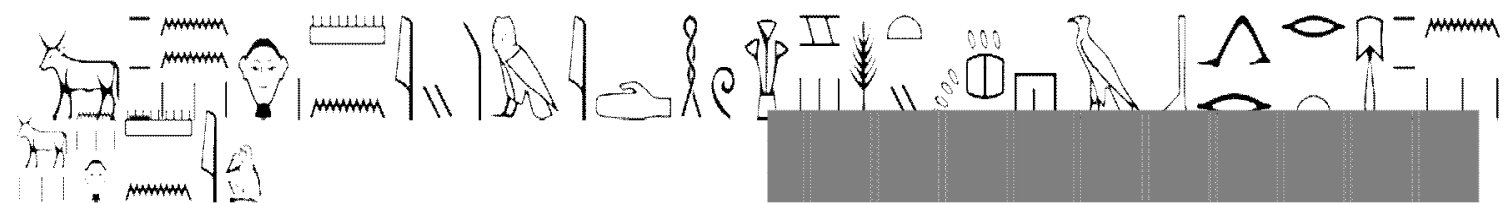

Our" cattle are in the papyrus marshes. Spelt is trodden out (?) for (?) our swine.

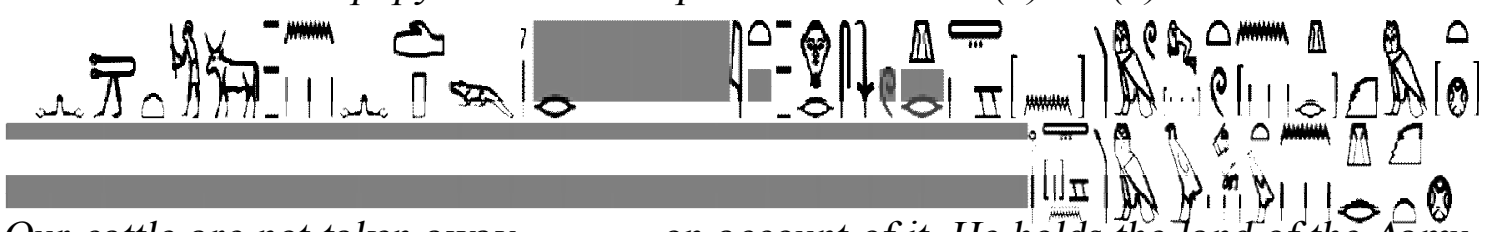

Our cattle are not taken away on account of it. He holds the Tand of the Aâmu, we hold Egypt.

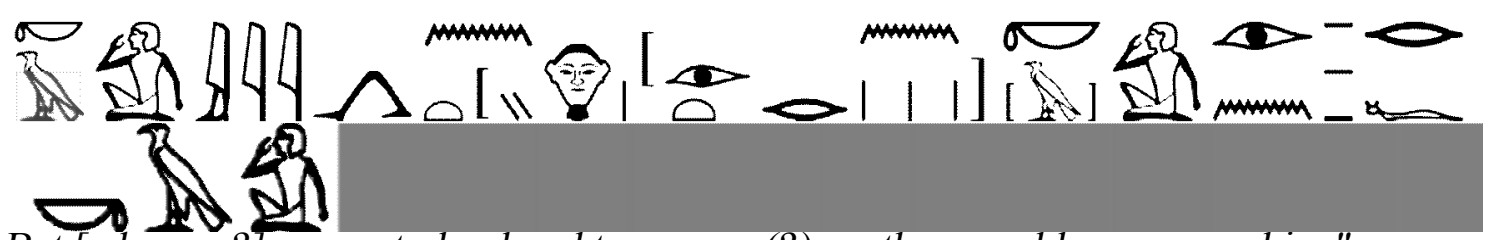

But [whoever?] comes to land and to oppose (?) us, then would we oppose him."

Comment:

Here the councilors of Kamose respond to their master, trying to assuage their lord's concern, by saying a good opinion of the Asiatics and the conditions are not completely bad, that the finest of their land were brought, plowing is done for them, cattle are in the papyrus 2.2.3. Kamose reaction \& decision:

marshes....etc.), but at last and before finishing their speech, they add a promise to act against anyone planning to attack. It seemed that the statement carries little conviction and was primarily to humor Kamose in his political worry.[12]

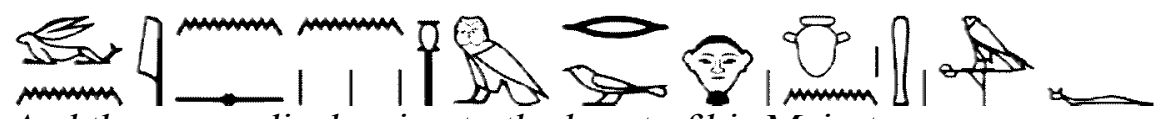

And they were displeasing to the heart of his Majesty 


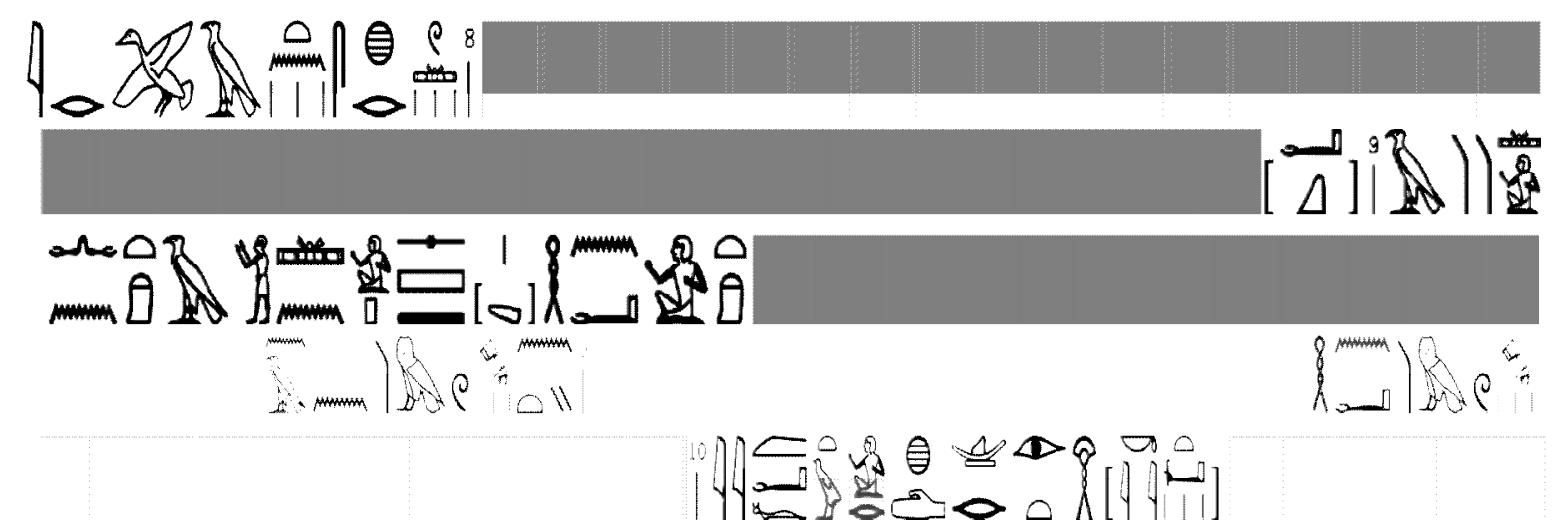

"As to this counsel of yours ............these A'amu who ......... [Behold I will fight (?)] with the A'amu

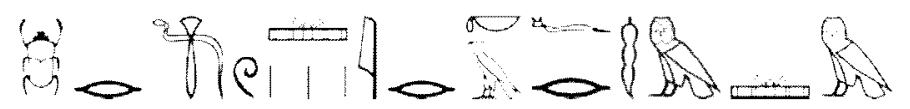

Success will come.

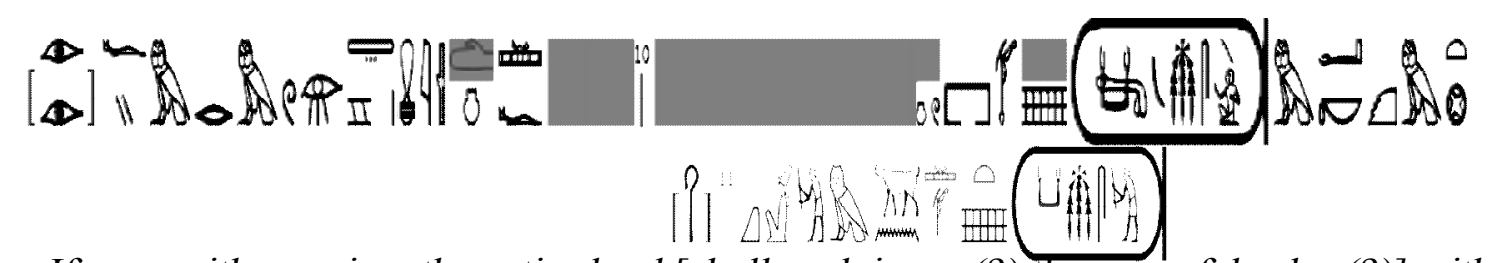

If........ with weeping, the entire land [shall acclaim me(?) the powerful ruler (?)] within Thebes, Kamose the protector of Egypt."

Comment:

Here Kamose is displeased over their pacifistic approach and haughtily rejects their words, so he at first rebuked his military councilors, and decided to fight the Asiatiques, that he sees himself as a victorious king and protector of Egypt. Suddenly the narrative opens, and from then on the first person is employed. At this point the text presents an account if spoken by Kamose himself. [14] We can observe here a real " Königsnovelle " scheme, that Kamose was the exact champion, and his decision was the strongest to protect Egypt from the enenmies, so he (Kamose) not any person else, was the beginner of this hard mission of liberation, so we find the auther of this tale stresses the unique role of Kamose by using Kamose's oath to fight the Asiatic '

At the command of Amun, whose forecasts are (always) correct, I sailed downstream to beat back the Aamu, with my valiant army (going) before me like a flame of fire ... ' [15] Here Kamose sailed by the Nile northwards to Nefrusi at middle Egypt to fight the Asiatiques, the specific type of warfare is barely presented in detail. On the contrary, we first hear of the siege at Nefrusi that seems to have taken place without any immediate opposition. Here Kamose sailed by the Nile northwards to Nefrusi at middle Egypt to fight the Asiatiques, the specific type of warfare is barely presented in detail. On the contrary, we first hear of the siege at Nefrusi that seems to have taken place without any immediate opposition.

\section{Royal Council at the 18th Dynasty}

The literary form of depicting the king summoned his councilors had been continued, as though the scribes of the beginning of the New kingdom were still

following the standard pattern of the Middle Kingdome and the Second Intermediate Period. Spalinger [16] see that the scene which depicted the king 
with his counsel , begin with:- 1) King Appearance, followed by 2) Sitting, and

\subsection{Battle of Megiddo}

One of the most famous literary forms was the report of the successful campaign against foreign lands; the ancient Egyptians used a war council between the king and his Generals and Advisors to stress the importance of the king and his decision. The details of the battle of Megiddo are mentioned, in whole or in part, in - at least - eight additional sources over and above the daybook experts. In the earliest account the composing scribes are impressed by three things: the initiative of the king in leading the way, the seizure of richly adorned chariots, and the submission of the chiefs. $\left[17^{]}\right.$We know that the great king (Thutmose III), at his first year ruled alone (the 22 year) begin an imperial military project at Asia Minor, 3.1.1. Council of war

After $19^{\text {th }}$ days on the march, the Egyptian army arrived at Yehem, where it encamped and rested for the anticipated crossing of Carmel Mountains. The name of the town (Yehem), coming from the root meaning to watch or protect, indicates its strategic location protecting the opining to Wadi Ara and the Aruna road running over the mountains to Megiddo. [20]Thutmose III is depicted as holding a council of war with his Generals (army commanders) in preparation for an advance on the city of Megiddo where a large of enemy forces had been existed. Here Thutmose continues the developed character of the royal figure as military leader. According to De Buck [21] the dialogue between Thutmose III and Generals at Aruna should not be a genuine account,
3) Discussion , as based on Middle Kingdom description of this theme .

proceeding to Megiddo castle, The first Campaign of Megiddo was in Thutmose III's estimation the most significant military exercise in his life. This battle was inscribed its events in details at specific place at holy precinct of Amon Re at Karnak temples, which known as (The Annals of Thutmose III), on the walls surrounding the Braque shrine of Amun at the temple of Karnak, fig. (3). This type of military account has been the subject of studies undertaken by Grapow and Noth.[18] In these daybook reports are performed dramatically by the scribes, who employed a common lexicon within a fixed arrangement [16] and were charged with recording the King's movements and activities each day, whether he was on campaign or not, [19]

even though there may have been a historical basis for such a scene. That the King must be depicted as a victorious King, especially on the march and in battle. The purpose of holding this military counsel, that there were two possible and safer routes leading to the castle of Megiddo, one called (Taanach) is $8 \mathrm{~km}$ to the southern east and the other (Djefty) is $5 \mathrm{~km}$ to the northern west, and there is a third route which is leading also to Megiddo through the mountain but it is narrow and dangerous[22]. The sentence in col. 19 until the col. 49 was some notice of a council of war within the day-book entry for that day; but the exact verbatim statements would not have been recorded.

\subsubsection{Part 1}

The Dating: [23]

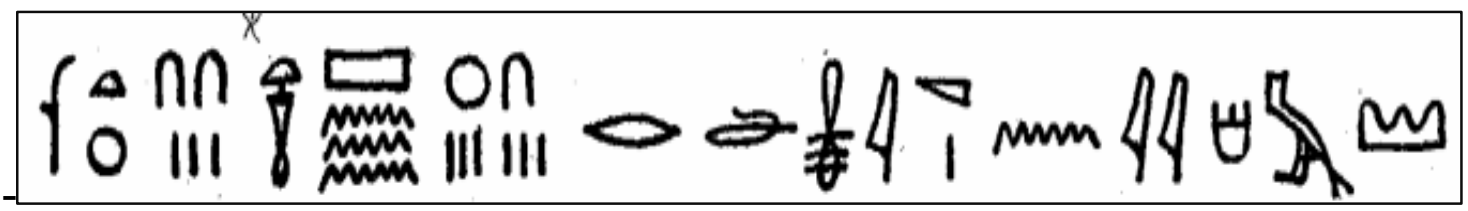


"Year 23, $1^{\text {st }}$ month of Šmw, day 16 toward the area of $Y \mathrm{hm}$ ". Here the diary is not told the date of arrival the city of $Y \mathrm{~m}$, there is no specification whence the advance started that day, only its aim. The goal is specified as $Y \mathrm{hm}$ which has been identified with Yemma on the northern foothills of the Carmel ridge. [24]

\subsubsection{Part 2}

King speech [23]

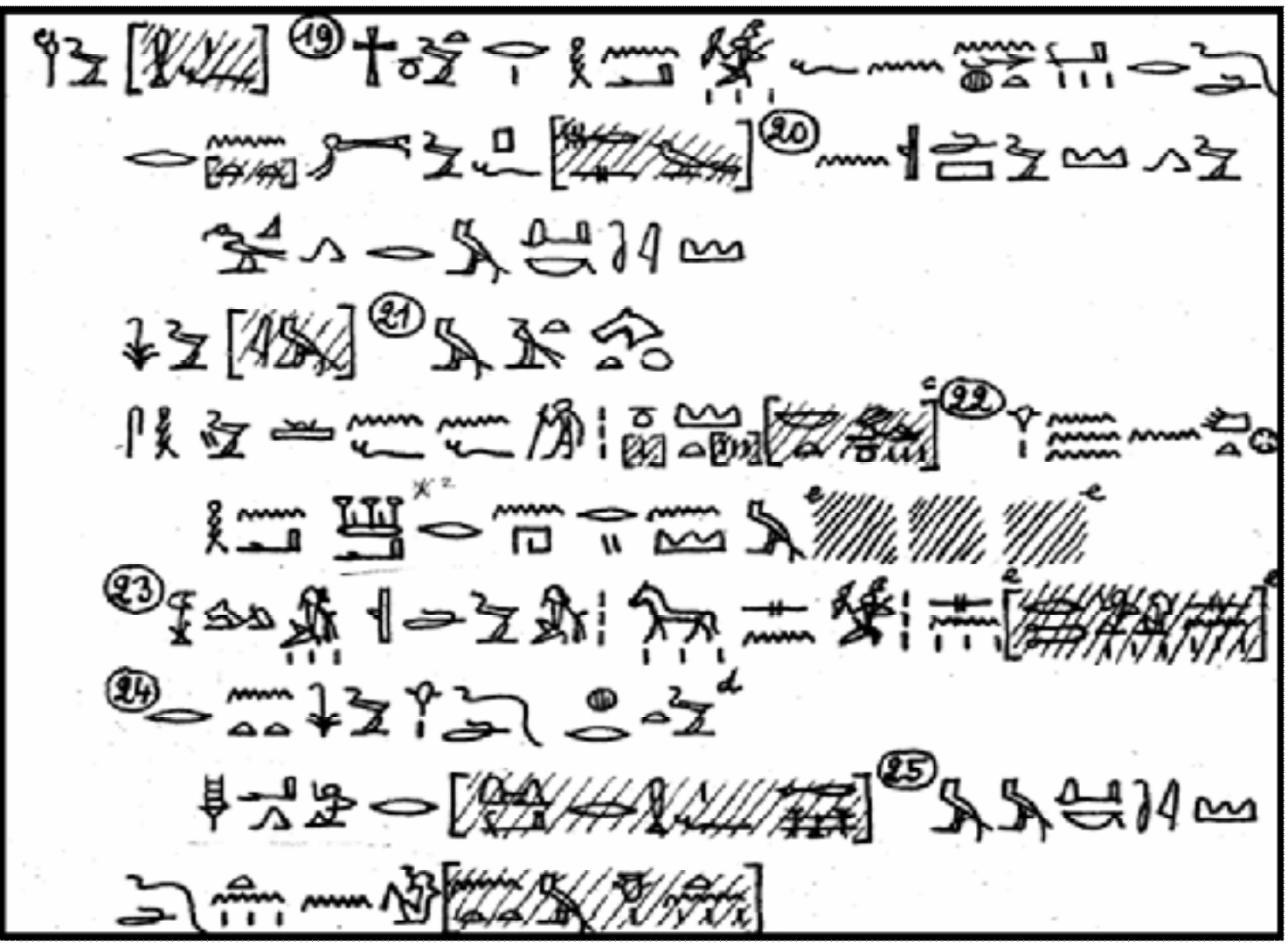

"His majesty commanded a consultation with his troop of nhtw to speak the following: that enemy [May he be miserable] of Qadesh, he has come and has entered to Megiddo. He is [there] in this moment, after he has gathered to him the chiefs of [various] foreign lands [that had been] loyal to Egypt and from Comment

This is a typical Daybook report which describes the conference of Thutmose with his army commanders; clearly, this was an important day in the campaign, as an important command in order to discuss the best route to take to Megiddo.Here like Kamose' council, the king began the speech to his councilors, but Borrowing freely from the " Königsnovelle "tradition, the "Annals" as far as Naharin M[ariannu], Kharu and Qedu, their horses, their fighters [and their people]."To the following: he is saying, so one says, I will wait to [fight against His Majesty here] in Megiddo". "You shall say to me [what is in your heart!]" [25]

omit bombastic phraseology, and without the angry dialect which characterized Kamose speech, Thutmose speech was quite and based on informatics reports.It is interesting to note that the crucial question of the crossing is not decided by Thutmose, but that it is the topic of war council.The scene begin with directly conference ( ndjwt-ra) of the king Thutmose III and 
his army commanders, we notice that within the genre of tomb biography a number of terms refer to interaction between the king and his courtiers in regard to discussion and decision making. ndjwt-ra 'consultation' is often found when the king is consulting the god as an oracle (see urk IV 833,15834,3 ); however it was used here to describe interaction between the king and his officials.[19] it lacks the famous introduction of the king 's counsel ( the Sitting of the King ) before discussion, so Spalinger [16] see, unlike the bland speeches in the " $K$ nigsnovelle" texts, the scribe used a summary of the enemy's plans and depicted the King inquires into the opinions of his army leaders, but without details concerning "how the king is in possession of specific information whereabouts of his enemy". Now the composition of the enemy force has been discussed and recognized as presented by Thutmose III to be made up of rebel chiefs in addition to mercenaries of different background, the second point brought up by Thutmose III in the military council for the reaction of some of his military following is the local for the battle, that the "chief of Qadesh" had made the choice to fight at Megiddo, since this would be his right as the challenged one according to the rules of war. He put it in the form of a reported pronouncement, considering the fact that Thutmose III is actually surprising his opponent in a rather strung-out condition, and not at all ready to fight, makes one wonder if the choice of the place of the battle had not actually been made by Thutmose III, but he concealed this from his troops. [25]
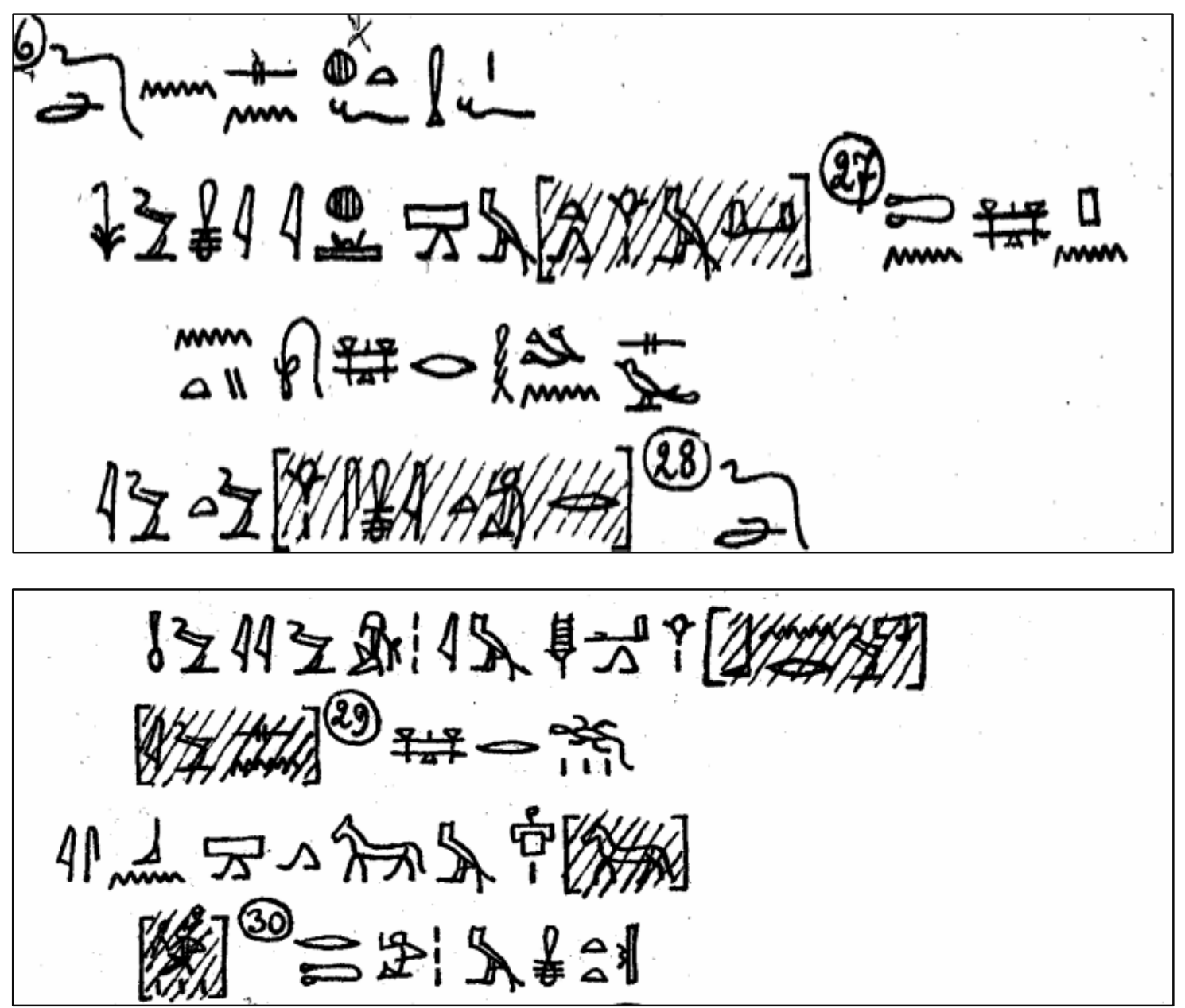

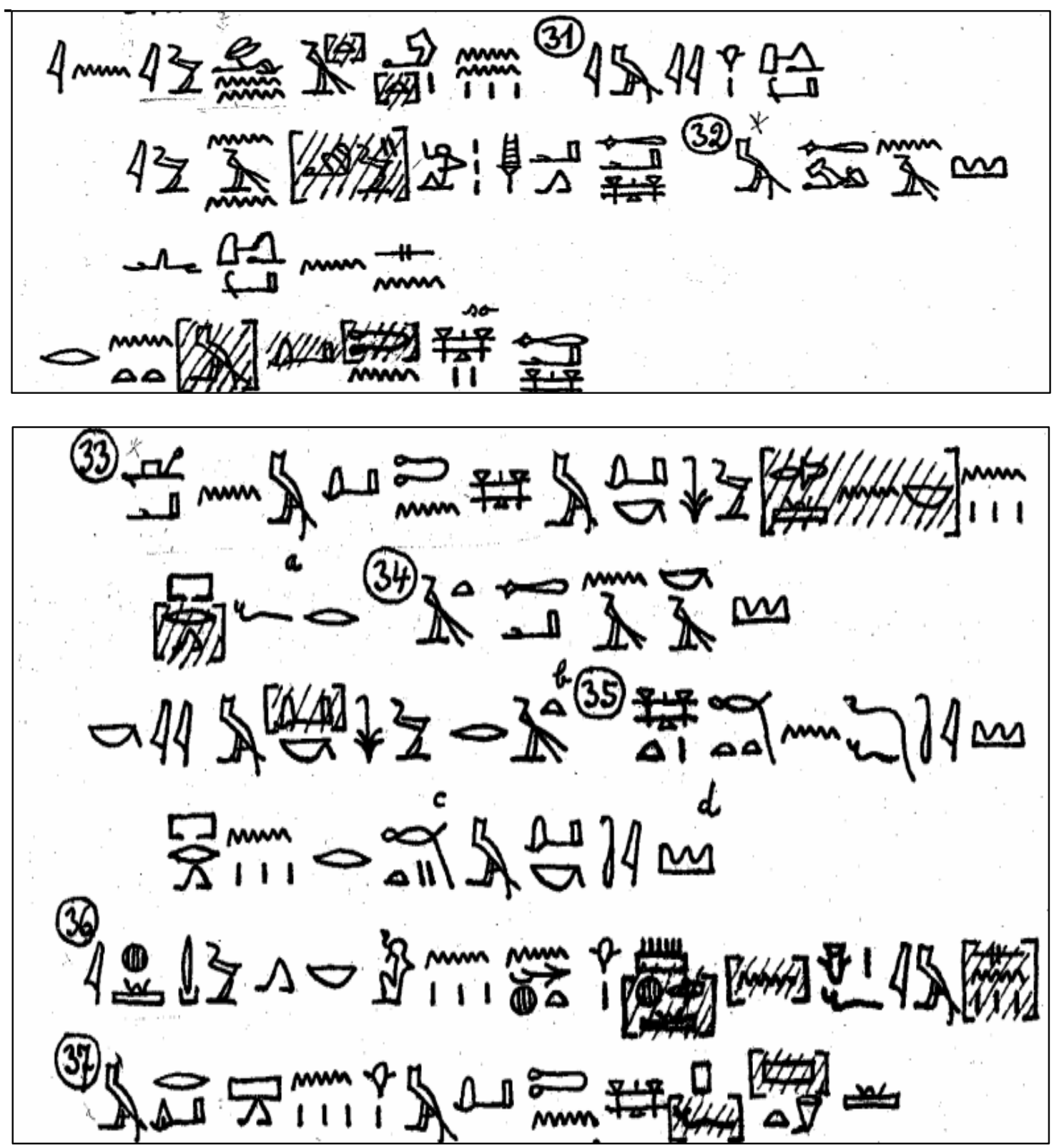

"They said before his Majesty: 'In what fashion shall [one] go forth from this path, which tends to be narrow, when one [responds] to the saying: 'The enemies there are stationed on [the outside] and they have gotten numerous. Lo, horse can go only after [horse, fighters] and men likewise. Will it not be that our tete will be fighting, while the [rear] is positioned here in Aruna without that they can be fighting'. Comment:

We notice here that the Thutmose army commanders expressed their opinion about the difficulties of choosing Aruna road which (according the text) was not suitable to march the army with its equipments,
'Furthermore, there are two paths here, one path, so it [is pleasing] to our [lord], he will advance towards Ta'anakh; the otherso it is (pleasing to our lord, he will advance) towards the northern road of Djefti! 'We wish to advance to seize Megiddo! 'Therefore, may our mighty lord proceed upon the road his heart is pleased in? $\mathrm{O}[\ldots .$.$] do not cause that we go on that$ difficult path! "[25]

and the enemies there are stationed on [the outside] and they have gotten numerous, so they enumerated their excuses which seemed to be logically acceptable. But Thutmose had a different vision. 
3.1.2. Thutmose III decision
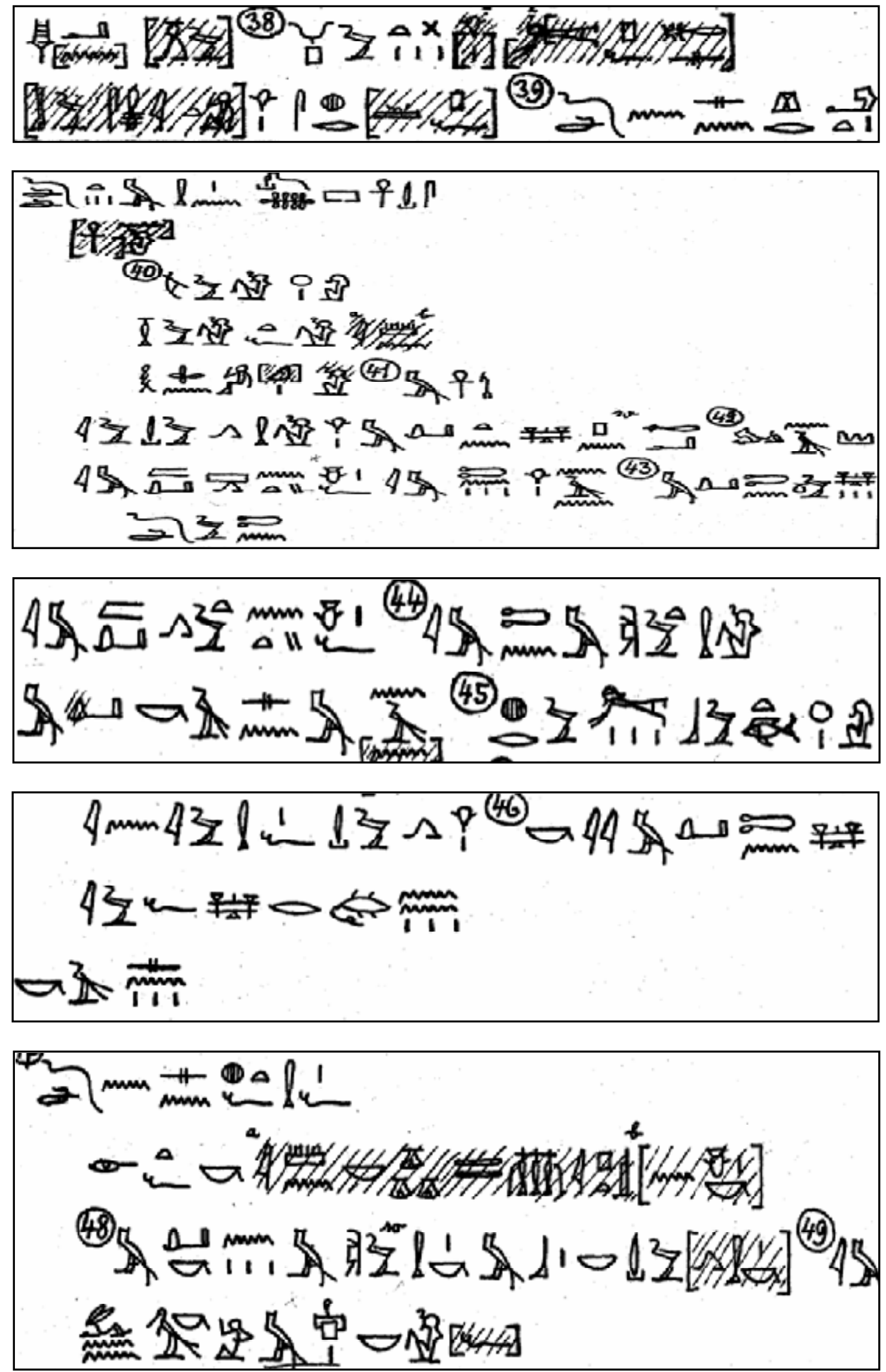

27 
"And then, when the opinions about the 2 paths were said, then His Majesty spoke about this matter, which they had said previously." What was said in the body of the privy council, life, property, health:'[As for m] e as my father Amon favors me and as my [nose] is vigorous with life and luck- My Majesty shall proceed on this path of Aruna! Cause that the one whose heart is in you goes on the paths which you are told! Cause that the one whose heart is in you come comes in Comment:

Clearly, the Yehem stop was the venue for not only the council of war, but also for the instruction and final disposition of the line of march; only after Aruna would such a deployment have been necessary. The textual embellishment seeks to lay stress on the king's courage and solicitude for his army. [2] It seemed that this paragraph is concerning with the arrival of additional reports about the place of the enemy, so Thutmose III wished to make like a strategic session to chose safety 3.1.3. Date and Time of the Conference According to Spalinger studies [16] concerning the text, he suggests:

a- Urk.IV 649.3: The arrival at Yhm: Day 16. b- Urk.IV 649.4: The Conference (ndjwt-ra) with his commanders at Yhm; no immediate decision: day 17.

Of these three routes Thutmose III suggested the third narrow route, so his Generals did not accept his choice, because the narrowness route will dangerously extend the Egyptian line of march, with " horse behind horse, and soldier behind soldier " with the result the Egyptian army advance to become in fighting without his rear. But Thutmose was insisted to proceed upon the Comment

The scribe used a summary of the enemy's plans and depicted the King inquires into the opinions of his army leaders, and this is quite different from the case of Kamose 's counsel, it seemed to be hostile conference, that Kamose announced his intentions but was met with the following of My Majesty! '"They will ponder, namely those enemy (soldiers) of the abomination- of-Re, 'Has his Majesty proceed on another way?' 'He has begun afraid of us! _ so they shall think!'"And they said before His Majesty:'May your father Amun, lord of Karnak, Foremost of Ipet-sut, act to your wish? We, indeed, are in the following of your Majesty in any place where [Your Majesty] proceeds! A servant is always behind his lord!" "125

place to begin the battle. After that we find Thutmose take his decision as he choose

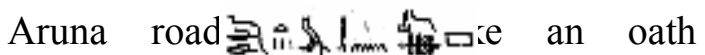
like Kamose perore(see pp11,12)for the same reasons which the scribe wished to the courage of his lord. Here the king played the main actor and presented as a person with human traits, a hero and decision maker, with specific focus on his deeds, and the success which he creates, however, he exceeds all humans in his abilities. [19]

c- Urk.IV 650.15: The arrival of the messengers (with different news than in Urk.IV 649.17ff.) and the king's fateful decision: day 17.

d- The arrival at Aruna: day 18.

dangerous road to take the enemies by surprise, while the other two routes are likely to reveal the Egyptian army movements well before beginning of the battle.[26] However, he adds, his generals are free to take their forces along the safer route, while the king leads his share of the army along the dangerous route to surprise and victory. At last they agree to follow him preceding the narrow dangerous road.

disappointment, the result Kamose became very angry and reprimanded his counsel. But here the conference of Thutmose was to be decided upon next military strategy, so it was quiet whether on the side of the king or that of his commanders. 


\section{Analyze of the three councils:}

The differences between Kamose and Thutmose councils, Kamose called together his "great men", meaning the nobles who were in the suite of their monarch. The ensuing report is therefore not concerned with an actual battle but instead with the opening salvos in a possible war. The King recommended an aggressive policy and the courtiers responded by offering a passive one. [14] Kamose, though displeased, preserved with his nationalistic war plans. Whereas we may contrast this account with that of Thutmose purely on the basis of the

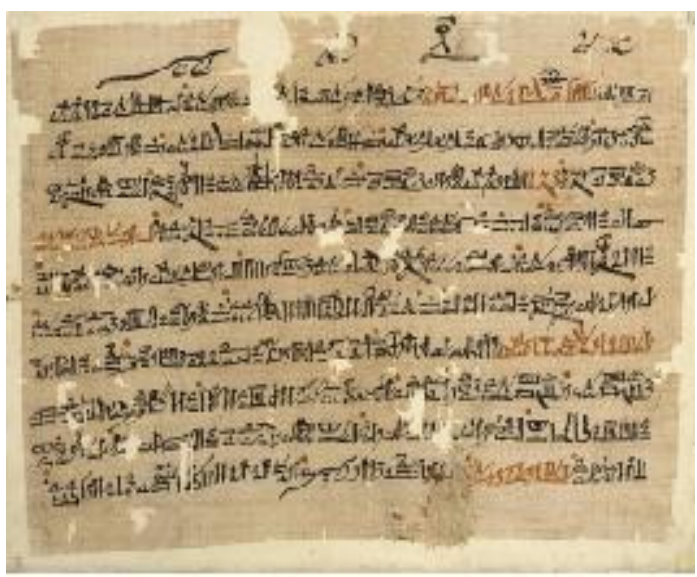

Figure (1): p. Sallier 1 - British museum

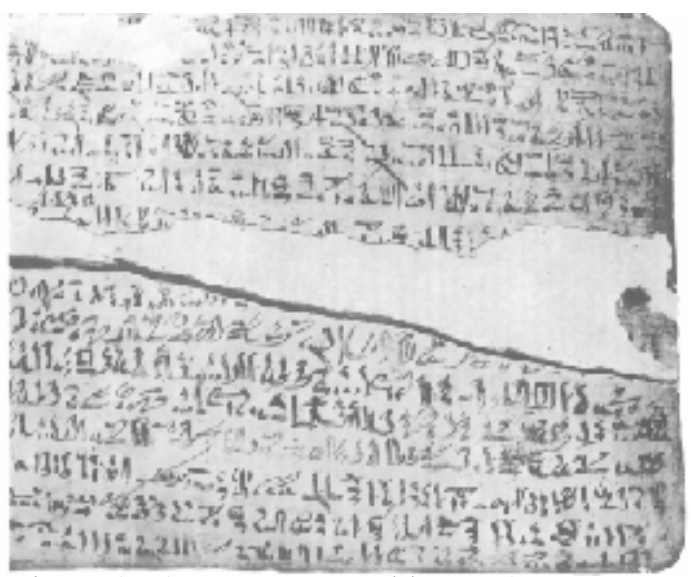

Figure (2 b): Carnarvon Tablet no.1) discussion and the retort of Kamose, it must be kept in mind that the second was not yet on the march. In the later case we witness the actual strategy to be taken in a war. In the Megiddo account, the image of Thutmose III is a fair and evenhanded one. The King does not falter. He neither shows cowardice nor acts as a martinet. It is assumed from the onset that Thutmose is an effective warrior. [14] The conference in the Megiddo report avoided the strategic objective but instead concentrated upon tactics of marching and the road to take.

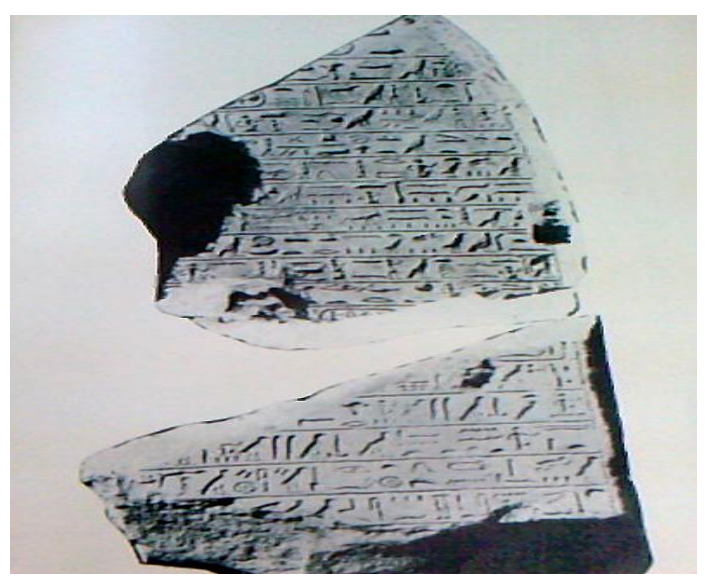

Figure (2 a): Kamose first stele

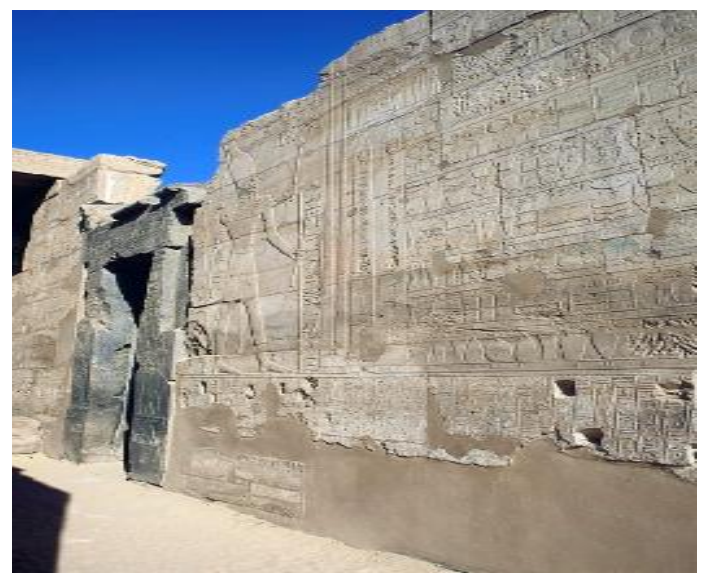

Figure (2 b): Hall of Annals of Thutmose III Karnak temple)

\section{Conclusion}

Council of war was held and recorded in ancient Egyptian history; this council was called by the king to take an important and hard decision with his councilors. The location of holding the council and the identity of members of councilors were differentiated from council to the other, it may be holding at the palace or at the battle field, as for the councilors whom were high officials, military commanders, scribes, wise men, priests. A decision making is the most thing at any council, mostly the king is describing as (the decision maker), that the result of his order 
and decision must be the wise and the best choice, to describe the king as the ideal and hero man (konigsnovelle).

\section{References}

[1] Hermann A., ( 1960) Die Ägyptische Königsnovelle, OLZ 55,s19.

[2] Redford D.B., (2003) The Wars in Syria and Palestine of Thutmose III, CHANES 16, Leiden, pp.19-22

[3] Goedicke H., (1986), The Quarrel of Apophis and Seqenenre, Chicago, pp.1-32

[4] Jenni H., (1998) Der Papyrus Westcar, SAK 25, pp113-141

[5] Blackman A.M., (1988) The story of King Kheops and the Magicians, London, p.1-17

[6] Quack S.G., (1992) Studien zur lehre fur Merikare, Wiesbaden, s.30

[7] Shaw G.J., (2008), Royal authority in Egypt's 18th dynasty, BAR Inter.Ser.1822,p.75

[8] De Buck, (1938) The Building Inscription of the Berlin Leather Roll ", in Studia Aegyptiaca 1, Rome, pp.48-57.

[9] Budge E.A.W., (1923) Facsimiles of Egyptian Hieratic Papyri in the British Museum, Second Series, pls LIII-LV; A.Gardiner, (1932) Late Egyptian Stories, Bibliotheca Aegyptiaca 1.

[10] Gunn B. \& Gardiner Alan H., (1918) New Renderings of Egyptian Texts: II. The Expulsion of the Hyksos J E A, Vol. 5, No. 1, p.4045

[11] Säve-Söderbergh T., (1951) The Hyksos Rule in Egypt, JEA Vol. 37, p. 67

[12] Goedicke H., (1995) Studies about Kamose and Ahmose, Baltimore, pp 31-45

[13] Gardiner Alan H., (1916) The Defeat of the Hyksos by Kamōse: The Carnarvon Tablet, No. I, JEA Vol. 3, No. 2/3, p.95
[14] Spalinger A.J., (2005) War in ancient Egypt, Oxford, p.2,-102-

[15] Smith H.S. \& Smith A., (1976) A reconsideration of Kamose Texts, ZÄS 103, p.59

[16] Spalinger A.J., (1982) Aspects of the Military Documents of the Ancient Egyptians, London, pp.105136.

[17] Redford D.B., (2006) The Northern Wars of Thutmose III, in D.O'Oconnor (editor), Thutmose III, a new biography, Michigan, p.331

[18] Grapow, (1943) Studien zu den Annalen Thutmosis des Dritten und zu ihnen verwandten historischen Berichten des Neuen Reiches (Berlin, 1949); Noth, ZDPV 66, pp.156-74

[19] Shaw G.J., (2008) Royal Authority in Egypt's $18^{\text {th }}$ Dynasty, BAR Int. Series 1822, pp.-76-94

[20] Gabriel R.A., (2008) Thutmose III, the military biography of Egypt's greatest warrior king, Washington, p.93

[21] De Buck, (1929) Het Tepische en het Individuelle bij de Egyptenaren, Leiden, p. 17

[22] Maruejol F., (2007) Thutmose III, et la coregence avec Hatchepsout, Pygmalion, p.142

[23] Sethe K., (1961) Urkunden der 18 Dynastie ,vol.IV,649. 3,649, 4-13

[24] Faulkner R.O. , (1942) " The Battle of Megiddo", JEA 28, p.2

[25] Goedicke H., (2000) The Battle of Megiddo, Baltimore,p.26-38

[26] Cline E.H. \& O'Connor D., (2008) Thutmose III , A New Biography ,Mitchigan,p.2. 